\title{
OPHTHALMIA NODOSA DUE TO CATERPILLAR HAIRS*
}

\author{
BY \\ J. A. CORKEY \\ Belfast
}

CASES of ophthalmia nodosa attributable to caterpillar hairs have been recorded in the literature from time to time during the last hundred years. The first description was published by Schön (1861) and further cases have been described by others including Pagenstecher (1883), Wagenmann (1890), Elschnig (1895). The name ophthalmia nodosa was given by Saemisch (1904). Only two British authors have published case reports: Lawford (1895), and Foster Moore (1929). The case here presented is the first to be recorded in Ireland and is one of a very small number which has been studied histologically. In preparing this account the valuable articles by Villard and Dejean (1934), and by Gundersen, Heath, and Garron (1950) have been consulted. A full bibliography of the condition will be found appended to these articles.

Villard and Dejean (1934) describe the results of their studies of four cases and mention five others in which caterpillar hairs or material caused eye lesions, adding these nine cases to the forty previously reported. Two of their cases were studied in detail: in the first the eye was struck by a caterpillar's nest falling from a pine tree, and in the second dust from a nest entered the eye which was rubbed vigorously. In both cases hairs became embedded in the cornea and in the second there was a conjunctival nodule containing five or six hairs.

In the case recorded by Gundersen, Heath, and Garron (1950) a farmer rubbed his eye with a towel in which a caterpillar cocoon was lying. There was an immediate reaction, intense and prolonged, and several hairs were noted in the cornea and anterior chamber. Paracentesis and iridectomy were carried out and finally, seven months after the accident, the eye was enucleated. A description is given of the histological findings.

In both these articles the authors proceeded to investigate the irritant effects of caterpillar hairs on rabbit eyes. In these animals the reaction was found to be milder than in man.

Among the points made by other writers the following quoted by Villard and Dejean (1934) may be noted. Teutschlaender (1908) gave an account of the penetration of the iris. He stated that free and dead caterpillar hairs were less irritant than those from a living insect, and ascribed the irritation to a toxic substance secreted in the venom glands from which the

* Received for publication November 23, 1954. 
hairs arise, the toxin being conveyed in a channel existing in the axis of the hair. Weill (1926), who removed a hair by iridectomy from an affected eye, also remarked on the virulence of living hairs.

The hairs are described as being of a chitinous substance and shaped like rigid barbed needles. Owing to their brittle nature the barbs are easily broken off and thus spread irritation further through the tissues; they are so placed as to hinder rather than facilitate the entry of the needle and thus tend to tear the tissue on entering it. Several different types of venomous caterpillar have been noted, among them Thaumatopoea pityocampa and Bombyx. Gundersen and others (1950) had difficulty in identifying their caterpillar, but thought Isia isabella might be involved; R. I. Lloyd in discussing this paper mentioned that vegetable hairs might also set up ophthalmia nodosa, instancing hop vine and burdock. This point is also noticed by Duke-Elder $(1938,1940,1954)$.

There is general agreement among all the authors dealing with this subject on the immediate and severe reaction to which the entry of these noxious hairs into the eye gives rise. In a typical case, after a very stormy week or so, the inflammation tends to subside, and then after a period of 6 to 8 weeks a recrudescence takes place with prolonged inflammation of the eye. In this phase the nodular reaction to the presence of the hairs is seen, most commonly in the conjunctiva. When the hairs were seen to lie in the substantia of the cornea, little surrounding reaction was noted. Gundersen and others (1950) state that hairs were present in the iris, choroid, or retina in 10-20 per cent. of the fifty reported cases.

The pathological appearances on microscopical examination are recorded as falling into two phases. First there occurs a liquefactive necrosis which may be due to the highly toxic substance introduced with the hair. At this stage a polymorphonuclear exudate is present and may give rise to hypopyon. In the later stages granulomata occur; these are composed mainly of mononuclear and epithelioid cells, but with multinucleated foreign body giant cells and the characteristic hair or spur occupying the centre of the lesion. No Koch's bacilli are present although the reaction is similar to that found in a tuberculous nodule.

Parker Heath, discussing Gundersen's paper, asked whether a sensitization reaction was involved after repeated exposure rather than a purely toxic effect. The finding that gave rise to this suggestion was the difficulty in securing more than a mild reaction in rabbits with the hairs of the offending (dead) caterpillar in his case and with those of Isia isabella which it was thought might be the caterpillar involved.

In the present case the essential history was not supplied until some time after the eye had been removed and the condition had been diagnosed histologically by Dr. Norman Ashton. Considering the case in retrospect, it is easy to feel that a clinical diagnosis might have been made, but in view of 
the multiple penetration of the coats of the eye and the presence of many hairs in the iris and ciliary body it is unlikely that the eye could have been saved.

\section{Case Report}

A boy aged 6 years was struck in September, 1952, on the left eye by an insect which had been brought home and thrown up into the air by an elder brother. Approximately a year later when questioned, this elder boy stated that it was a caterpillar that he had thrown. The patient cried sorely when the insect struck his eye and rubbed his eye vigorously. His mother bathed the eye but next morning it was swollen and closed. Bathing was carried out and the eye seemed to become fairly well, but about a month later it became red and inflamed. Atropine and sulphonamide were prescribed by the general practitioner, and as the inflammation persisted the boy was sent to hospital. Unfortunately, he was not accompanied to hospital by his parents, and no history was obtainable. He was sent on the next day to the Benn Eye Hospital, Belfast, and on December 6, 1952, the left eye was found to have ciliary injection, posterior synechiae, and new formed vessels on the iris. An $x$ ray of the eye revealed no radio-opaque foreign body, Mydricaine was injected and the inflammation having subsided to some extent the child was discharged on December 22. A week later he was brought back for review, and a parent gave the history that he had sustained an injury when out playing. On this occasion when the eye was relatively quiet, slit-lamp examination was carried out, and it was noted that there were many vessels in the cornea and iris. There was also noted a " globule on the iris with a ? eyelash in the centre". This was situated at about 7 o'clock. As there was no evidence of a penetrating wound, the possibility of a cilia was discounted. Two weeks later the iris was found to be extensively bound down to the lens and to be vascularized. There was good projection of light. Dionine drops 2 per cent. were prescribed and on the next attendance 2 months later, the eye was found to be irritable, with keratic precipitates, and to have no perception of light. It was therefore enucleated on April 1, 1953, some 6 months after the initial injury. The eye was sent to the Institute of Ophthalmology, and reported on as follows by Dr. Norman Ashton:

May 21, 1953.-Preliminary sections of this case have shown a nodular irido-cyclitis due to plant or caterpillar hairs-probably the latter. This condition of ophthalmia nodosa is a rarity, in fact only two cases have been reported in England and none from Ireland.

September 21, 1953.-Sections of the whole eye have shown the corneal epithelium to be of irregular thickness and the substantia propia vascularized and infiltrated with chronic inflammatory cells. Bowman's and Descemet's membranes appear normal. In the region of the lower limbus there are two oval lesions consisting of granulation tissue which centrally contain a circular foreign body found on dissection to be a fine pointed hair. Similar lesions with varying degrees of giant cell and inflammatory reactions are present in the subjacent ciliary body and in the lower iris, which is involved throughout its extent. In the angle formed by the iris and the ciliary body there is a dense mass of fibrous tissue in which scattered hairs may be seen; eosinophils were not found.

A further lesion is present in the choroid at the ora serrata. As many as twenty of these circular zones of reaction were seen in the affected area which is confined to the inferior aspect of the globe. The hairs were found to be non-refringent to polarized light. A diffuse inflammatory reaction was seen in the inner layers of the retina with some perivasculitis, peripapillary oedema, and occasional clumps of cells on the internal limiting membrane; there was a widespread loss of ganglion cells. The upper iris, ciliary body, and choroid showed a mild focal inflammatory infiltration. The lens (cut separately) appeared normal. The histological appearances are those of ophthalmia nodosa due to caterpillar hairs (Figs 1, 2, 3, and 4, overleaf). 


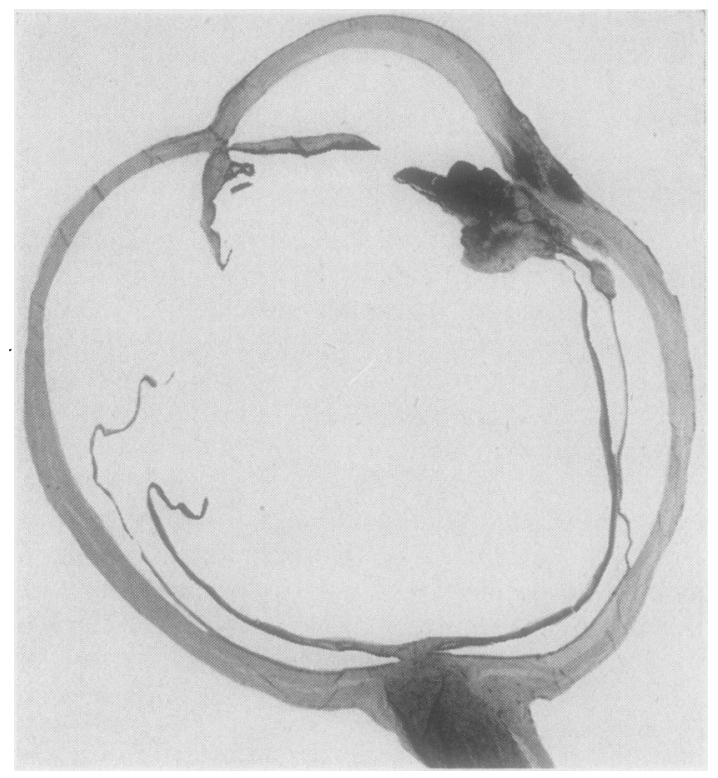

FIG. 1.-Section of whole eye showing nodular mass of granulation tissue replacing lower iris and ciliary body. The overlying limbus and the adjacent choroid contain oval inflammatory foci.

Fig. 2.-Inflammatory nodule in iris containing centrally a caterpillar hair engulfed within a giant cell. Haematoxylin and eosin. $\times 90$.

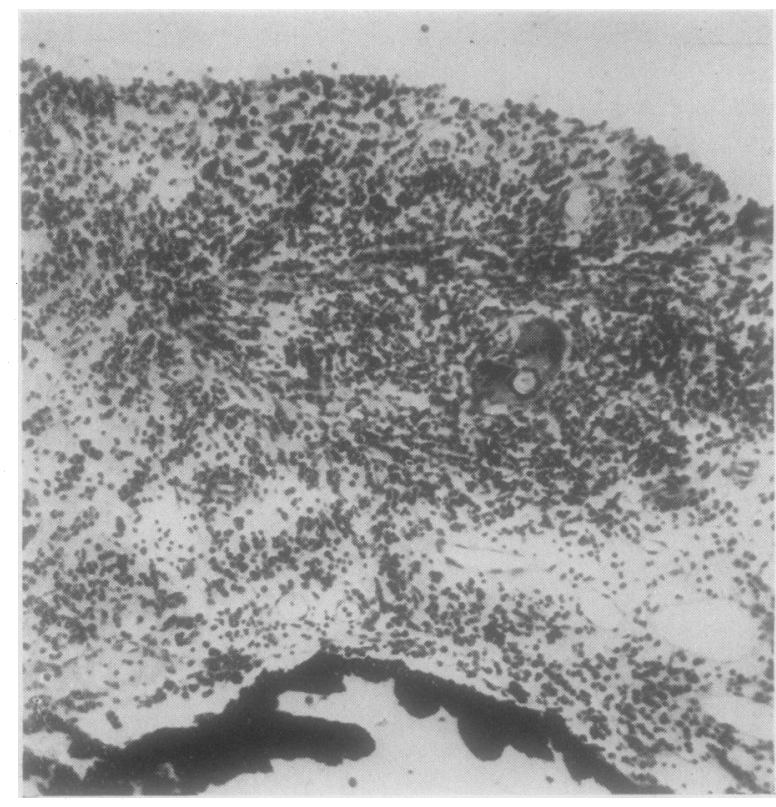

\section{Discussion}

Villard and Dejean (1934), in dealing with the treatment of this condition, emphasize the importance of prophylaxis both in education about the dangerous nature of such accidents, and in avoiding rubbing the eye when 
Fig. 3.-High-power view of caterpillar hair surrounded by granulation tissue and giant cells. Haematoxylin and eosin. $\times 480$.
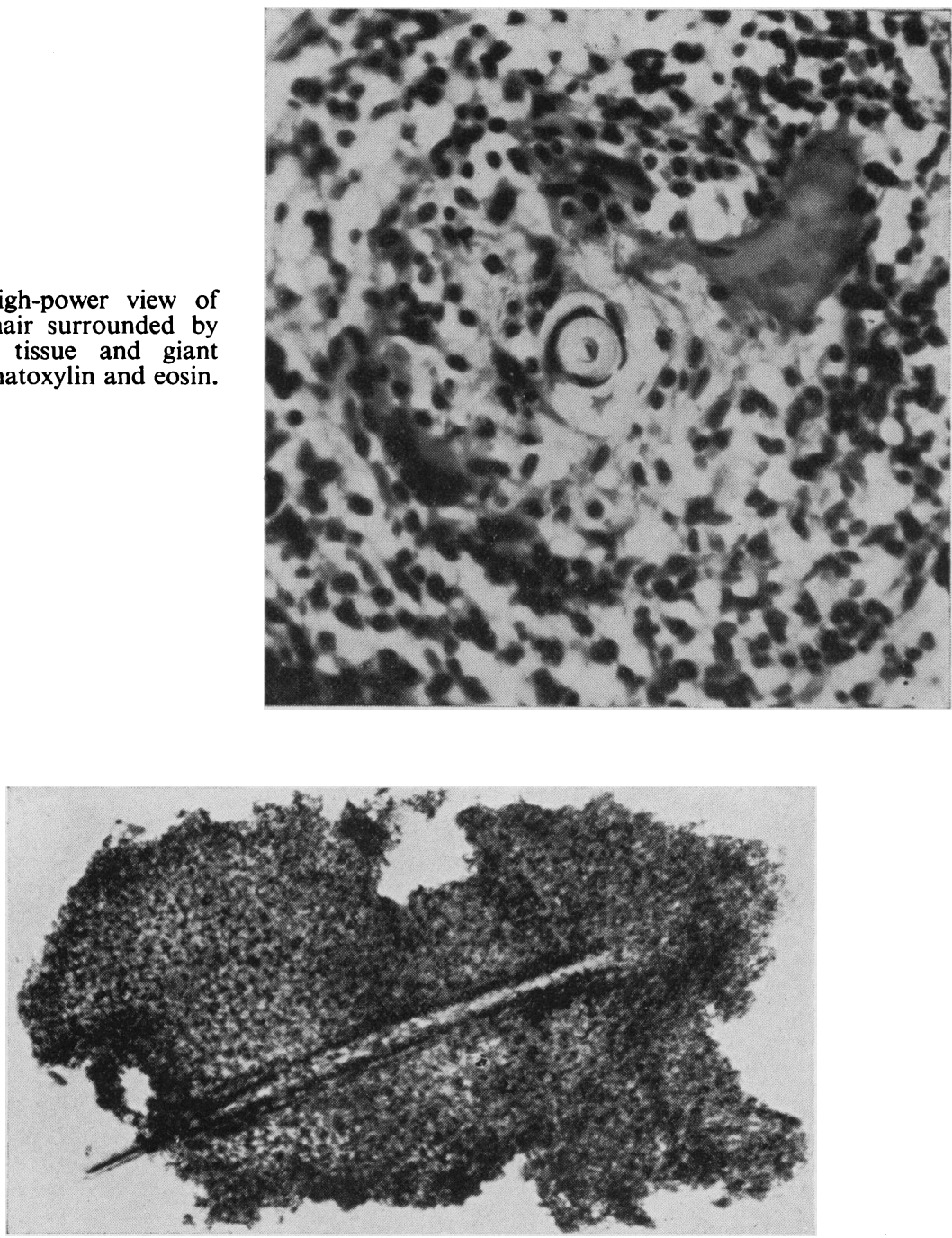

Fig. 4.-Piece of tissue dissected from iris nodule containing a needle-like caterpillar hair. $\times 120$.

an accident has occurred. Copious irrigation (à grande eau) and immediate removal of the hairs if practicable are indicated.

In many cases the inflammation eventually subsides and the foreign material appears to be tolerated.

Surgical treatment is of doubtful benefit in conjunctival cases. It may be required for a single nodule but is not feasible in the presence of multiple nodules. Enucleation should be reserved for phthisical and painful eyes.

Regarding the probable nature of the woolly-bear caterpillar involved, 
Mr. C. D. Deane, Keeper of Natural History in the Belfast Museum, states that the caterpillar of the Garden Tiger moth, Arctia caia, the common woolly-bear caterpillar, is often brought into the museum in August, and he has had personal experience of irritation in the eye caused by this creature.

\section{REFERENCES}

Duke-Elder, S. (1938). “Text-book of Ophthalmology ", vol. 2, p. 1718. Kimpton, London. (1940). Ibid., vol. 3, p.2368. (1954). Ibid., vol. 6, p.6762.

Euschnig, A. (1895). Klin. Mbl. Augenheilk., 33, 182.

FOster MOORE, R. (1929). British Journal of Ophthalmology, 13, 57.

Gundersen, T., Heath, P., and Garron, L. K. (1950). Trans. Amer. ophthal. Soc., 48, 151.

LAWFORD, J. B. (1895). Trans. ophthal. Soc. U.K., 15. 210.

PAGENSTECHER, H. (1883)!' Ber. ophthal. Ges. Heidelberg, 15, 176.

SAEMisCH, T. (1904). "Graefe-Saemisch Handbïch der gesamten Angenheilkunde ", 2nd ed., Band 5, Abt. 1, Teil 1, p.548.

SCHÖN, J. M. A. (1861). Beitr. prakt. Augenheilk., p. 183.

Trutschlaender, O. (1908). Arch. Augenheilk., 61, 117.

Villard, H., and DeJEAN, C. (1934). Arch. Ophtal., 51, 719.

WagenmanN, A. (1890). v. Graefes Arch. Ophthal., 36, pt. 1, p. 126.

WeILl, G. (1926). Bull. Soc. franc. Ophtal., 39, 143. 